\title{
BIK is a novel pro-apoptotic target gene for miR-125b in human monocytes
}

\author{
I Duroux-Richard ${ }^{1,2}$, J Presumey ${ }^{1,2}$, Y M Pers ${ }^{1,2,3^{*}}$, S Fabre ${ }^{1,2,3^{*}}$, C H Lecellier ${ }^{2,4,5}$, J Gruen ${ }^{6}$, T Häupl ${ }^{6}$, A Grützkau ${ }^{6}$, \\ G Burmester ${ }^{6}$, C Jorgensen ${ }^{1,2,3}$, F Apparailly ${ }^{1,2,3+}$
}

From 5th European Workshop on Immune-Mediated Inflammatory Diseases

Sitges-Barcelona, Spain. 1-3 December 2010

\section{Introduction}

The high numbers of activated cells in rheumatoid arthritic (RA) joints critically contribute to the persistence of chronic disease and have been associated with their resistance to undergo apoptosis [1]. Activity of pro- and anti-apoptotic Bcl-2 family members is constrained by transcriptional and/or post-transcriptional controls. As part of the post-transcriptional gene regulatory network machinery, micro(mi)RNAs represent an important class of endogenous, short, non-coding RNA that decreases gene expression by pairing to target transcripts and inducing gene silencing. Among miRNAs that have been assigned oncogenic and/or tumor suppressor-like functions, miR-125b is of particular interest. Among the dozen of genes that are identified so far as miR-125b targets, three are directly involved in apoptosis, all encoding for pro-apoptotic proteins: Bmf, BAK1 and p53 [2-4].

\section{Aim}

To provide novel insight into the integrated genetic regulatory network specifying cell fate, we have explored other pro-apoptotic members of the Bcl-2 family in the context of miR-125b and analyzed their respective expression levels in RA.

\section{Methods}

miRNA databases were used to detect potential miR125b responsive elements within the 3'-UTR mRNA of pro- and anti-apoptotic genes. The human monocytic cell line THP-1 was co-transfected with the reporter system containing the BIK 3'-UTR down-stream of the luciferase together with either a synthetic miR-125b

† Contributed equally

${ }^{1}$ INSERM, U 844, Montpellier, France

Full list of author information is available at the end of the article precursor or antagonist. Inhibition of the luciferase activity was compared with cells transfected with the mock construct. BIK expression and apoptosis were monitored at mRNA and protein levels after transfection of THP-1 monocytes with pre- or antago-miR-125b. Finally, miR-125b and BIK were quantified by RT-qPCR in blood samples from RA and healthy donors.

\section{Results}

We identify miR-125b, whose expression was highly correlated with patients with RA, as a post-transcriptional regulator of the pro-apoptotic BH3-like protein BIK. Moreover, enforced expression of miR-125b in human monocytes promoted apoptosis by targeting BIK in a dose-dependent manner, and broadly impacted apoptosis-related genes as assessed by transcriptomic analysis.

\section{Conclusion}

Understanding the mechanisms that alter the balance of anti- and pro-apoptotic proteins and identifying key molecules able to re-establish tissue homeostasis will open novel fundamental and therapeutic potentials.

\section{Author details \\ ${ }^{1}$ INSERM, U 844, Montpellier, France. ${ }^{2}$ Université Montpellier1, UFR de Médecine, Montpellier, France. ${ }^{3} \mathrm{CHU}$ Lapeyronie, Service Clinique d'Immuno- Rhumatologie, Montpellier, France. ${ }^{4}$ Université Montpellier 2, Montpellier, France. ${ }^{5}$ Institut de Génétique Moléculaire de Montpellier UMR 5535 CNRS, Montpellier, France. ${ }^{6}$ Rheumatologie, Charité, Berlin, Germany.}

Published: 25 November 2010

\section{References}

1. Hutcheson J, Perlman H: Apoptotic regulators and RA. Current Rheum Reviews 2008, 4:254-258.

2. Le MT, Teh C, Shyh-Chang N, Xie H, Zhou B, Korzh V, et al: MicroRNA-125b is a novel negative regulator of p53. Genes Dev 2009, 23(7):862-76. 
3. Xia HF, He TZ, Liu CM, Cui Y, Song PP, Jin XH, et al: MiR-125b expression affects the proliferation and apoptosis of human glioma cells by targeting Bmf. Cell Physiol Biochem 2009, 23(46):347-58.

4. Zhou M, Liu Z, Zhao Y, Ding Y, Liu H, Xi Y, et al: MicroRNA-125b confers the resistance of breast cancer cells to paclitaxel through suppression of pro-apoptotic Bcl-2 antagonist killer 1 (Bak1) expression. J Biol Chem 2010, 285(28):21496-507.

doi:10.1186/1479-5876-8-S1-P56

Cite this article as: Duroux-Richard et al.: BIK is a novel pro-apoptotic

target gene for miR-125b in human monocytes. Journal of Translational Medicine 2010 8(Suppl 1):P56.

Submit your next manuscript to BioMed Central and take full advantage of:

- Convenient online submission

- Thorough peer review

- No space constraints or color figure charges

- Immediate publication on acceptance

- Inclusion in PubMed, CAS, Scopus and Google Scholar

- Research which is freely available for redistribution

Submit your manuscript at www.biomedcentral.com/submit
C Biomed Central 